\title{
LEARNING, STRATEGIZING, AND ORGANIZATIONAL ROUTINES IN THE PRODUCT DEVELOPMENT PROCESS FROM A DYNAMIC CAPABILITY PERSPECTIVE
}

\author{
GERMANA T. MELO ${ }^{1}$ \\ (iD) https://orcid.org/0000-0003-1863-3802 \\ ANDRÉ G. C. MACHADO 2 \\ https://orcid.org/0000-0002-0589-896X
}

To cite this paper: Melo, G. T., \& Machado, A. G. C. (2020). Learning, strategizing, and organizational routines in the product development process from a dynamic capability perspective. Revista de Administração Mackenzie, 21 (5), 1-27. doi:10.1590/1678-6971/eRAMR200153

Submission: Aug. 30, 2019. Acceptance: May 26, 2020.

1 Federal University of Paraíba (UFPB), Bananeiras, PB, Brazil.

2 Federal University of Paraíba (UFPB), João Pessoa, PB, Brazil.

\section{(c) $\mathbf{B Y}$}




\section{ABSTRACT}

Purpose: To understand how learning, the constituent elements of strategizing and organizational routines act in the process of product development, from the perspective of dynamic capabilities (DC), in a company of the food sector.

Originality/value: To the extent that the learning-practice-routine trinomial is addressed, the results of this research present new and enlightening insights for the understanding of how dynamic capabilities are developed. Additionally, by considering the role of practitioners in the constitution of routines and by identifying how they relate to practices and praxis, evidence advance knowledge on the subject.

Design/methodology/approach: Qualitative approach through the selection of a company that has worked overtime in the development of new products. The data were collected through non-participant observation, documentary analysis, and narrative interview. Data analysis occurred through narrative analysis.

Findings: Through the appropriation of practices and the institutionalization of praxis, the strategic routines are enacted by practitioners, who accumulate and generate learning capable of developing DC. Thus, the learning-practice-routine trinomial allows to reveal how the DC are developed. In addition, the important role that practitioners play in this process was evidenced in the sense that, without them, routines are not enacted and, consequently, there is no development of DC.

\section{KEYWORDS}

Dynamic capabilities. Learning. Strategizing. Routines. Product development. 


\section{INTRODUCTION}

The intense rivalry between players in the business world has demanded efforts focused on the obtaining of new sources of competitive advantage. Amongst them, the development of dynamic capabilities (DC) can be highlighted, as they can explain the superior performance of one firm in relation to another in situations of rapid and unexpected changes (Teece, Pisano, \& Shuen, 1997). From the starting point of this understanding, a profusion of studies about this approach began to be published. However, they lacked consensus, which made a deeper understanding of the theme more challenging (Cardoso \& Kato, 2015; Maranzato \& Salerno, 2018).

Amongst the questions susceptible to debate, it is included that one about how the development process of DC occurs (Zollo \& Winter, 2002; Feldman \& Worline, 2012). However, there is an agreement between researchers (Teece et al., 1997; Eisenhardt \& Martin, 2000; Zollo \& Winter, 2002; Pavlou \& El Sawy, 2011; Meirelles \& Camargo, 2014; Bingham, Heimeriks, Schiiven, \& Gates, 2015; Tallott \& Hilliard, 2016) about the fact that learning constitutes an organizational process by which the DC are developed. Biesenthal, Gudergan, and Ambrosini (2019), for their part, called attention to the fact that DC are composed of routines, which cover rules and systems, courses of action, and behavior.

Thus, for the purposes of this article, we can understand dynamic capability as "a learned and stable pattern of collective activity through which the organization systematically generates and modifies its operating routines in pursuit of improved effectiveness" (Zollo \& Winter, 2002, p. 340). This concept involves not only the necessity of understanding the learning processes, but also the engagement in the activities and in how people perform these activities (Regnér, 2008). This last perspective is in line with the concept of strategizing, which is inherent in the strategy as practice (SAP) perspective, which occurs by way of the inter-relation between three elements: praxis, practices, and practitioners (Jarzabkowski, Balogun, \& Seidl, 2007).

Therefore, it can be perceived that the sociological perspective (SAP) and economic perspective (DC) of strategic management can enrich each other (Baum \& Dobbin, 2000) and various academics have encouraged associations between diverse approaches of this strategy (Amit \& Schoemaker, 1993; Johnson, Melin, \& Whittington, 2003; Peteraf, 2005). However, even though recent research contemplates new findings about DC and learning 
(Tallott \& Hilliard, 2016; Meira, Machado, \& Gomes, 2019), DC and routines (Wohlgemuth \& Wenzel, 2015; Garcia, 2017), SAP and routines (Feldman, 2015), and SAP, learning and routines (Silva \& Lucena, 2015), there is no evidence of studies that have adopted, together, practices, learning and routines to understand the DC development process. Besides this, Belmondo and Roussel (2014) point out that the inter-relationship between praxis and practice, intrinsic to strategizing, is not clear, suggesting new research that evaluates if the connecting element to fill in this gap could be in routines.

Considering the context presented, the research problem was synthesized in the following question:

- How learning, the constituting elements of strategizing and organizational routines act in the DC development process?

To respond to this question, the DC selected for analysis was that of product development (Eisenhardt \& Martin, 2000; Zollo \& Winter, 2002) in a food sector company, founded in 1951, and whose revenue in 2017 was BRL 609 million. This company has one of the most modern manufacturing plants in Latin America, composed of 12 industrial lines and approximately 1,000 employees, and where more than 200 food items are produced.

Thus, the central objective of this article involves understanding how learning, the constituting elements of strategizing, and organizational routines act in the product development process, from the dynamic capabilities perspective, in a food sector company.

By using the learning-practice-routine trinomial approach, the results of this research present new and enlightening insights for the understanding of how DC are developed. Additionally, the investigation of the role of practitioners in the constitution and execution of routines, highlighting how they relate to practices and praxis, advances knowledge on the subject.

The article is structured in the following way: first, the introduction is presented. Next, the following themes are addressed: DC, learning, SAP, and organizational routines. Then, the methodology is explained, and finally, the findings and conclusions of the research are presented.

\section{THEORETICAL FRAMEWORK}

The theoretical framework is subdivided into two sections. The first addresses the themes of DC and learning mechanisms, and the second discusses SAP and organizational routines. 


\subsection{Dynamic capabilities and learning mechanisms}

The emergence of DC indicates the need for the explanation of superior performance by one firm in relation to another when faced by situations of rapid and unexpected changes (Teece et al., 1997). Even though the origin of DC is clear, the same thing cannot be said about how they develop (Zollo \& Winter, 2002; Feldman \& Worline, 2012). The knowledge about the sources that generate DC is still controversial, and academics in the area present interpretations that are open to discussion.

For example, Teece et al. (1997) allege that the competitive advantage of a firm comes from three classes of factors, which helps a firm to determine its DC, and they are: organizational and management processes (coordination/integration, learning and reconfiguration, and transformation); the position of its assets; and path dependencies (strategic alternatives available to a firm and the presence or absence of growing returns). Even though Helfat et al. (2007) agree with Teece et al. (1997) that processes are sources that generate DC, they affirm that the identification of the need or opportunity for change on the part of an organization is made through specific processes, such as: search processes, decision-making processes and those for change management, with the advantages originating from DC being dependent on the effectiveness of underlying organizational and management processes.

On the other hand, Eisenhardt and Martin (2000) explain that the constituting processes are open to imitation, and, because of this, the value of DC for obtaining competitive advantage is in the resource settings that they create and not in the capabilities themselves. Thus, DC are constructed from various starting points and along different paths. These same authors cite product development routines, alliance and acquisition routines, resource allocation routines, and knowledge transfer and replication routines as examples of organizational processes that could be understood as DC.

Zollo and Winter (2002) also work in line with this reasoning that processes are generating sources of DC. However, they place an emphasis on learning processes. Thus, they establish three learning mechanisms to support the creation and evolution of DC: the accumulation of experiences, knowledge articulation, and knowledge codification.

In relation to the accumulation of experience, the authors affirm that routines are stable patterns of behavior that characterize organizational reactions to internal or external variations. Even though this does not answer the question of how the routines are generated and developed (much less 
DC), it is suggested that they are developed by way of the learning process that involves the accumulation of experience. Therefore, the accumulation of experience refers to the central learning process by which routines are developed.

Pertaining to knowledge articulation, Zollo and Winter (2002) focus on the process through which implicit knowledge is articulated by collective discussions, interrogation sessions, and performance evaluation processes. In relation to knowledge codification, the same authors explain that, when identifying and selecting change in operational routines, or a new routine to be established, an organization should create a manual or tool to facilitate its replication and diffusion.

More recently, research has been published in line with this understanding of the existence of this relationship between learning and the development of DC. Meirelles and Camargo (2014) proposed an integrating model, whose determining elements of the existence of DC include the set of behaviors, abilities, routines, processes, and mechanisms of learning and knowledge governance focused on change and innovation.

For their part, Giniuniene and Jurksiene (2015) argued that DC are seen as a broad framework that explains how different routines and processes influence performance and help companies to maintain their competitive advantage. In this framework, organizational learning and innovation are two important processes that mediate the relationship between DC and a firm's performance.

Bingham et al. (2015) studied how the learning of a specific dynamic capability can influence the learning of other DC or, in other words, they investigated how more than one dynamic capability is learned at the same time. Tallot and Hilliard (2016), whilst studying about the development process of DC, found that DC can be developed intentionally by managers through strategic decision making and through deliberating learning within a path-dependent evolution.

Vargas-Hernández and Muratalla-Bautista (2017) did not study the influence of learning on the generation of DC, but rather the inverse process, concluding that the generation and development of management knowledge, in terms of organization's DC, lead to strategic learning and the potential for the absorption of this knowledge in organizational innovation. Regardless of this, a relationship can be perceived between learning and the development of DC.

For their part, Arndt, Fourné, and MacInerney-May (2018) explained the existing variations in the learning components of DC, contributing to 
the debate about routines versus deliberate learning in the development process of DC. In alignment with Zollo and Winter (2002), Meira et al. (2019), when analyzing the development of DC in the hospital accreditation process, provided evidence about the roles of the three deliberate learning mechanisms proposed by the first authors. In addition to this, in this same research, by means of the understanding of the trajectory of the capabilities over time (and its implications for routines), found two behaviors, that is, capabilities that either acted dynamically or operationally.

From the above, it can be verified that the set of authors mentioned converge on the conception that learning, in some way, is the organizational process by which DC are developed. This understanding necessarily goes through the understanding of how people carry out the activities that are inherent in the process and interact with each other. Thus, the perspective of the practice can clarify the way in which DC emerge, are developed, modified and transformed over time, thereby increasing the understanding of their essence (Jarzabkowski, 2005), and which is discussed in the following section.

\subsection{Strategy as practice and organizational routines}

SAP considers strategy as something which people do daily, and which involves their colleagues and is part of their work: a socially constructed activity (Whittington, 2006). It is related to detailed aspects of strategizing, that is, to how strategists think, talk, reflect, act, interact, get emotional, enlighten, politicize, which tools and technologies they use, and what are the implications of the different forms of strategizing for strategy as an organizational activity (Jarzabkowski, 2005). Therefore, strategizing has to do with administrative activity and the way by which strategists carry out strategy (Whittington, Johnson, \& Melin, 2004).

Strategizing is illustrated by means of the model presented in Figure 2.2.1, according to which the interconnection between practice, praxis and practitioners can be perceived. Letters A, B, and C correspond to the strongest points between one of these interconnections, depending on the problem to be investigated.

Praxis consists of the activities that people do in practice, and these practices can be cognitive, behavioral, procedural, discursive, motivational and physical, combined, coordinated and adapted to create a praxis; and practitioners refer to "actors that affect the construction of practices by what they are, by the way in which they act and by the resources that they utilize" (Jarzabkowski et al., 2007, p. 11). 


\section{(Figure 2.2.1)}

\section{CONCEPTUAL MODEL TO ANALYZE STRATEGY AS PRACTICE}

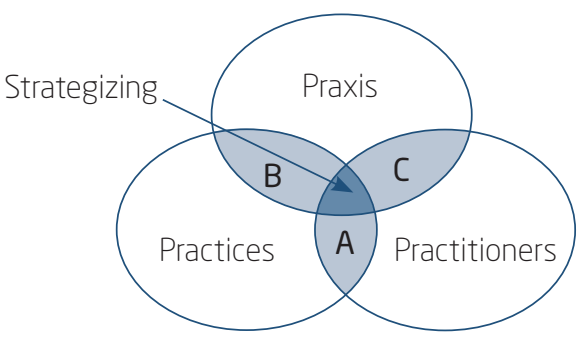

Source: Adapted from Jarzabkowski et al. (2007)

Jarzabkowski (2005) presents his understanding of practices in a more structured way, categorizing them into three types: administrative, discursive, and episodical. Administrative practices like planning mechanisms, budgeting, forecasting, control systems, performance indicators and goals, serve the objective of organizing and coordinating strategy. Discursive practices provide linguistic, cognitive, and symbolic resources to interact with strategy. Episodical practices, such as in meetings, workshops, and away days, create opportunities and organize the interaction among practitioners in strategy elaboration (Jarzabkowski, 2005).

From the above, one can see that the model shown in Figure 2.2.1 explains the fact that strategizing occurs in the interconnection between practice, praxis, and practitioners. However, the interrelationship between these links, represented by letters A, B, and C, is not explained.

Evidence for this explanation can be found in the work of Belmondo and Roussel (2014), as they see routines as being the link between practices and praxis. For them, practices, as much as collective activities performed by individuals, are responsible for the emergence of strategic activities, which are characterized by repetition, being present in strategic routines, thus, ratifying that the relationship between praxis and practices is mediated by the routines present in an organization (Belmondo \& Roussel, 2014).

It is important to clarify that these routines are conceived as generative and dynamic systems and not as static objects, being a source of change flexibility. Thus, they are made up of two interactive aspects: the performative and the ostensive (Feldman \& Pentland, 2003).

The performative aspect is defined as "specific actions, by specific people, in specific places and times" (Feldman \& Pentland, 2003, p. 101) and, therefore, is related to the idea of praxis, seeing as both refer to the execution of 
activities performed by individual actors. These activities are institutionalized in an organization, in so far as they are repeatedly carried out during the frequent performance of a routine (Feldman \& Pentland, 2003; Pentland \& Feldman, 2005).

The ostensive aspect is conceptualized as "[...] the ideal or schematic form of a routine. It is the abstract, generalized idea of the routine, or the routine in principle" (Feldman \& Pentland, 2003, p. 101) and is related to strategic practices, as they provide practitioners with tools and techniques that can be employed to formulate and implement strategy, and that need to be appropriated so that they can be utilized effectively. Thus, it can be affirmed that strategic practices are collectively appropriated in routines when they provide tools and techniques utilized by the actors (Feldman \& Pentland, 2003; Pentland \& Feldman, 2005).

Therefore, routines result from the institutionalization of praxis and the appropriation of practices, as it can be seen in the conceptual model provided by Belmondo and Roussel (2014) and presented in Figure 2.2.2.

\section{(Figure 2.2.2) \\ CONCEPTUAL MODEL TO UNDERSTAND THE EMERGENCE OF STRATEGIC ROUTINES}

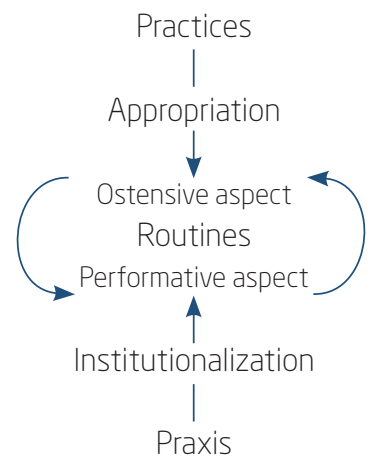

Source: Belmondo and Roussel (2014, p. 14)

The model demonstrates that strategic routines result from the appropriation of strategic practices and from the institutionalization of strategic praxis. It is possible to perceive the relevance that the practice approach possesses for the understanding of the development of DC, since they provide the elements (practice and praxis) that underpin the routines, which, in turn, constitute the element over which the learning mechanisms 
that support the creation and evolution of DC act. It also turns out that strategy and routines are recursively related and, because of this, the understanding that the study of routines contributes to research about SAP is also valid (Feldman, 2015).

\section{METHODOLOGICAL PROCEDURES}

This research presents a qualitative approach and the method adopted was that of narratives of practices that are considered relevant to study how strategizing is carried out (Rouleau, 2011). Two criteria were adopted for the selection of the company: 1. to have developed new products over time and 2. to be available to participate in the research within the time frame given.

The data were collected by means of non-participant observation (during a visit to the company), documental analysis and narratives from interviews. The activities performed by the workers in the working environment can be tracked through the observations, allowing for the understanding of the explanations supplied during the interviews. The documents were related to product development: a book commemorating the $60^{\text {th }}$ anniversary of the company; and a PowerPoint presentation used by the human resources training and development manager.

The interviewees were people whose jobs involved product development, obeying what SAP orientates them to do; not just strategic level workers performing strategy work, but also intermediate-level managers and consultants, for example. Thus, eight people were interviewed: the product development manager, the marketing manager, the national subsidiaries' manager, the commercial director, the industrial manager, the line manager, the quality control manager, and a consultancy professional. The number of interviewees was defined by the perception that the narrative of the interviewees already supplied sufficient information (data saturation) in the sense that they responded to the research objectives. The narratives from the interviews were recorded, transcribed, and achieved through four phases (Jovchelovitch \& Bauer, 2002):

- Initiation: the initial topic about which the narrator should talk was elicited (product development). Before the initiation phase, the interviewer went through a period of preparation, during which she familiarized herself with the field of study, which occurred through the reading of news published on the internet and the annotation of the informal 
account that came about during the initial conversation with the associate director of the company.

- Central narration: listening of the narration about the product development process gone through. The interviewees spoke about the following themes:

1) product development process;

2) underlying learning process for the product development process.

3) learning mechanisms utilized;

4) praxis episodes: meetings, consultancies, writings, presentations, communication etc. (Whittington, 2006);

5) practitioners: senior executives, intermediate level manages, analysts, coordinators, and consultants (Whittington, 2006);

6) strategic practices: administrative (planning mechanisms, budgeting, forecasting, control systems, performance indicators and goals), discursive (provide linguistic, cognitive and symbolic resources to interact about strategy), and/or episodic (create opportunity and organize the interaction between practitioners in strategy elaboration, as well as meetings, workshops and away days) (Jarzabkowski, 2005).

- Questioning: questions such as "What happened then?" were asked at the end of the narrative, with the idea to fill in gaps in the product development story.

- Conclusive speech: once the recorder had been turned off, pertinent annotations of informal comments were made, as well as questions such as "Why?".

Data analysis occurred through the analysis of the narratives. The narratives were put into chronological order after they were transcribed (Creswell, 2013), using a structure provided by Pentland (1999), according to which narratives have five fundamental properties and respective indicators for analysis: sequence (event patterns); focal actor(s) (role, social and demographic networks); voice (viewpoint, social relations, and power); moral context (cultural values and assumptions); and other indicators (other contextual aspects). After this, tables were created for the analysis of the interviews according to the aforementioned properties and the research objective.

\section{PRESENTATION AND DISCUSSION OF THE RESULTS}

Considering that processes are generating sources of DC (Teece et al., 1997; Helfat et al., 2007), through the analysis of the product development 
process, it was evident that, in line with Zollo and Winter (2002), this DC came about through the interaction between the following deliberate learning mechanisms: experience accumulation, knowledge articulation and knowledge codification (Figure 4.1).

\section{(Figure 4.1)}

LEARNING MECHANISMS

\begin{tabular}{|c|c|c|}
\hline Experience accumulation & Knowledge articulation & Knowledge codification \\
\hline $\begin{array}{l}\text { Professional experience gained } \\
\text { in the past; experience with } \\
\text { the development and launching } \\
\text { of previous products; } \\
\text { experience acquired whilst } \\
\text { participating in fairs and } \\
\text { courses. }\end{array}$ & $\begin{array}{l}\text { Informal conversations; } \\
\text { collective discussions; } \\
\text { meetings; training; company } \\
\text { corridors; fairs; courses; } \\
\text { participation in associations; } \\
\text { telephone; e-mail; visits to } \\
\text { points of sale. }\end{array}$ & $\begin{array}{l}\text { Procedures; Business } \\
\text { Automation System (BAS); } \\
\text { electronic spreadsheets; } \\
\text { minutes; forms; product sheet; } \\
\text { manuals. }\end{array}$ \\
\hline
\end{tabular}

Source: Elaborated by the authors.

The accumulation of experience is represented by professional experience gained in the past, experience with the development and launching of previous products and experience acquired while participating in fairs and courses. The marketing manager's account illustrates this:

We are accustomed to working with market observation and with the data that we have from the life of the company itself. Therefore, in the life of the company, we know, in the snacks line, which flavors are on the ascension, and which are not [...] And this is without the experience that you acquire along the way. You know that there are some flavors that are difficult for you to get a certain type of aroma because they are very volatile. You buy a certain type of aroma and, when it is ready for consumption, it has already become volatile; it is already different. Consequently, you have an experience that tells you what could work and what probably will not. Now the certainty of what will work or not will be determined by the market.

The accumulation of experience allows for the development of certain routines, which are shared by the mechanism of knowledge articulation and institutionalized via the mechanism of knowledge codification.

Consequently, 11 routines were revealed: market observation, suggestions of the presidency, workers or clients, approval/disapproval of ideas, knowledge acquisition to enable product development, the realization of 
tests in laboratories, sensorial tasting, approval/disapproval of samples, product approval, pilot tests, production for commercialization and product launches. They were identified based on the characteristics suggested by Milagres (2011), in accordance with which, routines should be collective, interdependent, standardized, and repetitive.

It can be observed that these routines correspond to the stages involved in the product development process of the company researched, showing the relationship between the development of DC and routines, and in line with the understanding of Wohlgemuth and Wenzel (2015), Garcia (2017), and Beisenthal, Gudergan, and Ambrosini (2019).

However, Belmondo and Roussel (2014) affirm that routines result from the institutionalization of praxis and the appropriation of practices, thus, demonstrating the necessity of utilizing the practice approach to understand how DC develop. Consequently, 31 strategic practices and their respective praxis episodes, during which routines occur, were identified (Figure 4.2). According to Jarzabkowski (2005) precepts, practices were categorized into administrative, discursive and episodical.

\section{(Figure 4.2)}

\section{PRODUCT DEVELOPMENT ROUTINES RESULTING FROM PRACTICES AND PRAXIS}

\begin{tabular}{|c|c|c|}
\hline Practice & Routines & Praxis \\
\hline $\begin{array}{l}\text { Nielsen report, interaction } \\
\text { moments and } 5 \mathrm{~S} \text {. }\end{array}$ & Market observation & Purchase tendency, visit stores, reading reports. \\
\hline $\begin{array}{l}\text { Nielsen report, interaction } \\
\text { moments and } 5 \mathrm{~S} \text {. }\end{array}$ & $\begin{array}{l}\text { Suggestion of President, } \\
\text { worker, or client }\end{array}$ & Purchase tendency, visit stores, reading reports. \\
\hline $\begin{array}{l}\text { Nielsen Report, project } \\
\text { elaboration, annual planning, } \\
\text { budgeting, interaction } \\
\text { moments and } 5 \text { S. }\end{array}$ & $\begin{array}{l}\text { Approval/rejection of } \\
\text { idea }\end{array}$ & $\begin{array}{l}\text { Verify the necessity for the implantation of a new } \\
\text { production line and costs to produce a new } \\
\text { product. }\end{array}$ \\
\hline $\begin{array}{l}\text { Interaction moments, concept } \\
\text { planning, action plan 5W2H } \\
\text { (what, where, who, why, when, } \\
\text { how, how much), brainstorming, } \\
\text { benchmarking, market } \\
\text { observation, 5S, procedures, } \\
\text { internal audit, Corrective and } \\
\text { Preventative Action Report } \\
\text { (Capar) and records. }\end{array}$ & $\begin{array}{l}\text { Knowledge acquisition } \\
\text { for product development }\end{array}$ & $\begin{array}{l}\text { Visit supermarkets. Study product legislation. } \\
\text { Reading reports. Purchasing similar products. } \\
\text { People interaction. Written description of the } \\
\text { procedures for knowledge acquisition. Audit } \\
\text { product realization. Fill in the Capar. Register } \\
\text { activities carried out for knowledge acquisition. }\end{array}$ \\
\hline
\end{tabular}




\section{(Figure 4.2 (continuation))}

\section{PRODUCT DEVELOPMENT ROUTINES RESULTING FROM PRACTICES AND PRAXIS}

\begin{tabular}{|c|c|c|}
\hline Practice & Routines & Praxis \\
\hline $\begin{array}{l}\text { Brainstorming, Plan, Do, Check } \\
\text { and Act (PDCA), Hazard } \\
\text { Analysis and Critical Control } \\
\text { Point (HACCP), Good } \\
\text { Manufacturing Practices (GMP), } \\
\text { 5S, Business Automation } \\
\text { System (BAS), market } \\
\text { observation, interaction } \\
\text { moments, celebrations, } \\
\text { meeting, procedures, internal } \\
\text { audit, Capar and records. }\end{array}$ & $\begin{array}{l}\text { Test carried out in } \\
\text { laboratory }\end{array}$ & $\begin{array}{l}\text { Test raw material samples from different suppliers. } \\
\text { Define the quantities of the ingredients. Define } \\
\text { quality parameters. Develop formulations. Prepare } \\
\text { samples for tasting. Elaborate electronic } \\
\text { spreadsheets. Write procedures for laboratory test } \\
\text { approval/rejection. Audit product realization. Fill in } \\
\text { the Capar. Record test activities. }\end{array}$ \\
\hline
\end{tabular}

Training, interaction moments, Sensorial tasting meetings, 5s, procedures,

internal audit, Capar and records.
Send e-mails. Invite tasters. Present developed product. Taste sample(s). Evaluate sample(s). Write tasting procedures. Audit product realization. Fill in the Capar. Record tasting activities.
Training, meetings, interaction Sample approval/ moments, market observation, rejection procedures, internal audit, Capar and records.
Carry out training. Conversations. Reading reports and studies. Written description of sample approval/rejection. Audit product realization. Fill in the Capar. Record the activities carried out for sample approval/rejection.

\begin{tabular}{|c|c|c|}
\hline $\begin{array}{l}\text { Meetings, interaction } \\
\text { moments, market observation, } \\
\text { procedures, internal audit, } \\
\text { Capar and records. }\end{array}$ & Product approval & $\begin{array}{l}\text { Conversations. Reading of reports and studies. } \\
\text { Written description of the product approval } \\
\text { procedures. Audit product approval. Fill in the } \\
\text { Capar. Record activities carried out for product } \\
\text { approval. }\end{array}$ \\
\hline
\end{tabular}

Brainstorming, PDCA, HACCP, Pilot test

GMP, 5S, BAS, market

Adjust machines and equipment. Waste percentage observation, interaction moments, celebrations, meeting, statistical control of weight, training, team performance index, procedures, internal audit, Capar and records. study. Production monitoring. Comparison of product with the established quality parameters. The forwarding of information to the production and quality control department, and elaboration of electronic spreadsheets. Written description of the procedures for the carrying out of the pilot test. Audit pilot test realization. Fill in the Capar. Record pilot test activities. 


\section{(Figure 4.2 (conclusion))}

\section{PRODUCT DEVELOPMENT ROUTINES RESULTING FROM PRACTICES AND PRAXIS}

\begin{tabular}{|c|c|c|}
\hline Practice & Routines & Praxis \\
\hline $\begin{array}{l}\text { Brainstorming, PDCA, HACCP, } \\
\text { GMP, 5S, BAS, market } \\
\text { observation, interaction } \\
\text { moments, celebrations, } \\
\text { meeting, statistical control of } \\
\text { weight, training, team } \\
\text { performance index, procedures, } \\
\text { internal audit, Capar and } \\
\text { records. }\end{array}$ & $\begin{array}{l}\text { Production for } \\
\text { commercialization }\end{array}$ & $\begin{array}{l}\text { Product presentation. Elaborate product claim. } \\
\text { Quality parameters. Machine/equipment } \\
\text { adjustment. Training. Sample review. Production } \\
\text { process review. Packaging elaboration. Team } \\
\text { orientation, training, and monitoring. Check to see } \\
\text { if the process began, sector organization, } \\
\text { production standard, raw material, and packaging } \\
\text { necessities. Identification of production } \\
\text { bottlenecks. Discussion about production process } \\
\text { improvements. Observe, reflect and perform } \\
\text { adjustments to the production process. Observe } \\
\text { sales. Contact other areas to verify the } \\
\text { compatibility or adequacy between that which is } \\
\text { being produced and what other areas are doing. } \\
\text { Written description of the commercialization } \\
\text { approval procedures. Audit commercialization } \\
\text { approval. Fill in the Capar. Record commercialization } \\
\text { approval activities. }\end{array}$ \\
\hline $\begin{array}{l}\text { Interaction moments, training, } \\
\text { meetings, procedures, internal } \\
\text { audit, Capar and records. }\end{array}$ & Product launch & $\begin{array}{l}\text { Launch and product presentation to salespeople } \\
\text { that are going to present the product to clients. } \\
\text { Product placement at the points of sale (store). } \\
\text { Hiring of an outsourced team for product } \\
\text { demonstration in the stores. Written description of } \\
\text { product launch procedures. }\end{array}$ \\
\hline
\end{tabular}

Source: Elaborated by the authors.

Since all the interviewees stressed the use of practice, it is present in the execution of most routines. The identification of routines associated with quality management practices, such as the $5 \mathrm{~S}$ program, was fundamental for Silva and Lucena (2015) to understand the practitioners' learning process. Through the diagnosis of routines, they highlighted the role of the search for information, people interaction and reflection about performance as key elements of this process.

At the beginning of the product development process, the routines of market observation and suggestions of the presidency, worker or client result from the appropriation of the administrative practice relating to forecasting, denominated the Nielsen Report (report elaborated by the company of the same name which studies and forecasts consumers' tendencies and habits), since through these reports a company can analyze and identify market 
opportunities and decide which product should be developed. Another practice consists of moments of social interaction, through which the practitioners exchange ideas to develop new products.

The routines, as also highlighted by Feldman and Pentland (2003), Pentland and Feldman (2005), and Feldman (2015), result from the institutionalization of a flow of activities (praxis) that goes from the purchase of Nielsen reports, to supermarket visits and to the reading of reports. It can be perceived that the connection between practices (Nielsen, interaction moments and 5S) and praxis (report purchase, supermarket visits, and reading of reports) is mediated by the market observation routine, allowing for an initial understanding of how the development of the dynamic capability (product development) occurs based on the practice perspective.

It also turns out that the idea approval/rejection routine results from the appropriation of five types of administrative practices: Nielsen reports, elaboration of projects, annual planning, annual budgeting, and 5S. The discursive practice of interaction moments is also present in the carrying out of the routine in question.

Based on the Nielsen reports, as much in projects as in planning, it is possible to continue with the analyses and evaluate the industrial viability, examined in terms of investment versus physical capacity, as reported by the commercial director: "makes a simple project with sales forecasting, forecasting of price per kilo, [...]. With these things, progress can be made, and the industrial feasibility will be evaluated [...] by way of investment versus physical capacity".

Thus, project elaboration helps the presidency decide if a product can be developed or not, as it allows for the visualization of the project's economic and industrial feasibility. The practices of annual budgeting and planning also directs product development, as, at the beginning of each year, each carries out planning that must be in line with the company's budget.

Finally, the social interactions that occur during the meetings between the practitioners and their other work colleagues, personal colleagues, suppliers, assembly line technicians, clients etc. allows for knowledge sharing that contributes to product development. The marketing manager explains this:

Everything is channeled to the meeting [...] if the person is not at the level of the meeting... the factory manager...he will go and speak to someone. He will not participate in the meeting, but he can talk with his director. Anyone can come and talk to me; a sales manager will seek his/her sales manager. There is this open channel to talk with 
someone that participates in the meeting and bring this suggestion here to the company's discussion forum.

All these practices provide important information so that the practitioners administrative-finance director, industrial director, commercial director, associate director, superintendence and the marketing manager can decide, during the praxis episode of a meeting, if the suggested product will be approved or not for development. Besides this, this decision requires the execution of a flow of activities that involve verifying the necessity for the implantation of a new production line, as well as the new product's production costs.

The research findings corroborate Jarzabkowski's (2005) assertions regarding practice categories since administrative, discursive and episodical elements were identified as the product development process went along. Besides this, the routine for knowledge acquisition for product development, for example, results from the appropriation of administrative practices (market observation, concept planning, action plan $5 \mathrm{~W} 2 \mathrm{H}$, brainstorming, benchmarking, procedures, internal audit, Capar and records), and from the discursive and/or episodical practice of the type of interaction moments, according to the account of the product development manager: "A technician always comes, who knows the line assembly and consequently knows the product. Then he/she gives tips, and we adapt things to what we want".

The aforementioned routine resulted from the institutionalization of the following praxis: visiting supermarkets, a study of a product's specific legislation, report reading, the purchase of similar products, and people interaction, as information coming from these sources can help in knowledge acquisition that will contribute to product development. Thus, in line with Giniuniene and Jurksiene's (2015) findings, a learning process is identified in the performance of a routine that influences an organization's performance.

Furthermore, there are routines for the written description of the procedures for knowledge acquisition, audit to verify how the knowledge acquisition to develop new products is being done, and the filling in of the Capar, which takes place when a non-conformity is identified.

In relation to the routine for the carrying out of a laboratory test, the product development manager explains that "any raw material that is going to enter $[\ldots]$, goes through the laboratory, testing, and then goes to the process that is the production line". This routine results from the appropriation of the following practices: brainstorming, PDCA, HACCP, GMP, 5S, BAS, market observation, interaction moments, celebrations, meeting, procedures, internal audit, Capar and records. 
The praxis activities that make up the referred to routine encompass testing raw material samples from different suppliers, defining the quantities of the ingredients utilized, defining quality parameters, developing formulations, preparing tasting samples, and creating electronic spreadsheets. Besides these activities, there are also those related to the written description of the procedures for the performance of laboratory tests, and audit to verify how the tests for new product development are being done, and the filling in of the Capar when a non-conformity is identified.

Regarding the sensorial tasting routine, the quality control manager explains that:

It is a group, this group tries the product and fills in a specific form, describing the feeling that they have in relation to the sensorial attributes of that product. From there, it is reached the conclusion that it is approved, being taken to the director president. He, confirming that product, is then free to take care of putting together the process.

This routine results from the appropriation of the following discursive practices: training, interaction moments, meetings and e-mails, as well as the administrative practices of control (procedures, internal audit, Capar and records), and from the institutionalization of the following praxis: sending e-mails, inviting tasters, presenting the product developed, tasting the sample(s), evaluating the sample(s), describing (in writing) the procedures for the performance of the sensorial tasting, audit to verify how the tasting takes place and filling in the Capar when a non-conformity is identified.

The routine performed after the sample tasting is that of sample approval/ rejection, as defined by the marketing manager: "after tasting, we select two or three of the most approved samples and take them to a meeting of the directors, together with the presidency to see if the product is approved or not. Upon approval, the product then goes to the pilot test stage to be made by machine".

Through the evidence reported, it can be perceived that this routine is performed through the appropriation of the administrative practices of market observation, as the tasters guide their decisions for the approval or rejection of the laboratory developed sample in accordance with what the market says is a tendency, and in accordance with the control (procedures, internal audit, Capar, and records). The other practices are episodical (training, interaction moments, and meetings), as, based on the sensorial tasting training and the interactions between the tasters, they decide if they approve or reject the sample. 
The sample approval/rejection routine is also a result of the institutionalization of the praxis of: the realization of training, conversations, reading of reports and research that reveal the market situation, as well as the written description of sample approval/rejection procedures, audits to verify how the samples are being approved or rejected, and the filling in of the Capar when a non-conformity is identified.

The product approval routine refers to the approval, by the directors, of the product developed from the samples selected by the sensorial tasting team, according to the quality control manager:

The final approval is never there...the day ends, we get a sample that we think it has the characteristics of the parameters previously defined, this sample goes to the tasting group, once approved by this group, it goes to the director president.

Except for the practice of training, the product approval routine results from the appropriation of the same practices utilized in the previous routine. The same happens with the praxis, except for the training realization praxis.

The next routine is the pilot test. The product development manager explains that:

We do the pilot test. The production staff participates [...] me with the Analyst on the part of development, and then there is the quality control part. Because I am developing, and we have to know if the product is coming out with the quality desired. Therefore, we do a pilot test.

The practices utilized in the execution of this routine are similar to those employed in the laboratory test routine, plus the appropriation of the practices of statistical control of weight, training and team performance index.

In relation to the institutionalization of the activities flow (which also contributes to the execution of the pilot test), the following can be highlighted: adjustment of machines and equipment, study of the waste percentage of raw material and packaging, production monitoring, comparison of the product developed with the quality parameters previously established, the forwarding of information to the production and quality control department, and elaboration of electronic spreadsheets.

Once the pilot test is working adequately, the production for commercialization routine begins, as defined by the marketing manager: "The product was already approved, and we want to see if this is maintained on the production 
line and also in the technical analyses: product density, humidity, temperature, the technical issue of the process. Then, if everything is okay...we then actually produce for sale".

This routine results from the appropriation of all the practices mentioned until now, as well as the institutionalization of all the listed praxis. It is also important to add the use of the following praxis: check if the process has begun, check the sector organization, check if the production is within established standards, check the necessity for raw material and packaging, identification of production bottlenecks, discussion about improvements in the production process, observe, reflect and perform adjustments to the production process, observe sales, get in contact with the other areas to verify the compatibility/adequateness between what is being produced and what the other areas are doing.

The product launch routine results from the appropriation of the discursive practices of interaction moments and training (of the people that will present the product to clients), the episodical practice of meetings, and the administrative practices of control (procedures, internal audit, Capar and records). The marketing manager explains how a product launch takes place: "When the quantity asked for is in stock, marketing releases the communication of product launch (by circular e-mail) to all those involved: logistics, invoicing, commercial, managers and purchasing".

The institutionalization of the praxis occurs through the execution of the following flow of activities: launch and presentation of the product to the salespeople that are going to present the product to clients (owners of supermarkets, bakeries and hotels etc.), product placement at points of sale (store) and the hiring of an outsourced team for product demonstration in the stores, written description of the product launch procedures, audit to verify how the new product launch process is taking place, and the filling in of the Capar when a non-conformity is identified.

The evidence resulting from the adoption of the viewpoint of SAP for data analysis allows for the complementation of the results from recently published research (Arndt et al., 2018; Meira et al., 2019), because, even though the authors had focused on understanding routines and learning mechanisms, the DC conception process can also be learned through interaction between strategizing elements.

The findings of this research also complement the model conceptually proposed by Belmondo and Roussel (2014), because the evidence reveals, in agreement with Feldman (2015), the importance of practitioners as the main people responsible for routine activation (Figure 4.3). 


\section{(Figure 4.3)}

\section{STRATEGIZING ELEMENTS IN THE EMERGENCE OF STRATEGIC ROUTINES}

Practices and practitioners

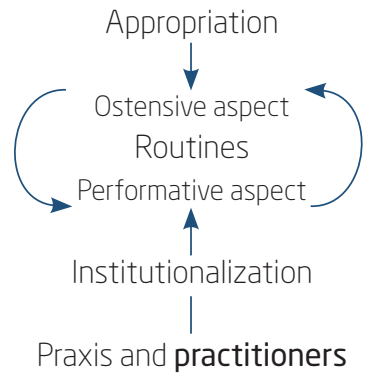

Source: Elaborated by the authors.

The model provided in Figure 4.3 not only ratifies the integrated vision between praxis, practice, and routines, considering routines as an intermediate level between praxis and practice, but also reveals that strategic routines are conceived and executed by practitioners.

\section{FINAL CONSIDERATIONS}

The objective of this study was to understand how learning, the constituent parts of strategizing, and organizational routines act in the product development process, from a dynamic capabilities perspective, in a food sector company.

It was found, from the understanding of Zollo and Winter (2002), that DC are developed from learning mechanisms and that, during the learning process, routines are generated. These, for their part, are formed from the appropriation of practices and the institutionalization of praxis (Belmondo \& Roussel, 2014), which raised the need for the utilization of the practice approach.

Thus, it was understood, principally through the technique of interview narrative, that learning mechanisms, especially that of experience accumulation, gave rise to a set of 11 product development routines (market observation, presidency, worker or client suggestion, idea approval/rejection, knowledge acquisition to enable product development, performance of laboratory test, sensorial tasting, sample approval/rejection, product 
approval, pilot test, production for commercialization and product launch). These routines are constituted from the appropriation of practices and from the institutionalization of the praxis presented. The other learning mechanisms will help in the sharing (knowledge articulation mechanism) and institutionalization (knowledge codification mechanism) of the product development routine.

This possibility of articulation between learning, the practice approach, and routines in the understanding of DC development constitutes a contribution to academia, in so far, as no articles were found in the literature that clarify, in a detailed way, DC development using the learning-practicesroutines trinomial. Furthermore, this study offers not only a theoretical base, but an empirical one, in relation to the understanding of DC development. Consequently, there is a practical contribution in the sense that DC are generating sources of competitive advantage and understanding their development process can help companies to achieve a superior performance.

It can also be added that the study highlighted the role of the practitioners, in the sense that they are responsible for the activation of routines. This means that, without practitioners' action, practices and routines are not activated, as well as praxis does not happen and, consequently, there is no DC development.

In view of the above, it can be confirmed that the central research objective was reached. However, even though Feldman (2015) defends a recursive relationship between practices and routines, in this study, only the practicesroutines relationship was analyzed. Thus, it is suggested that new studies should be developed that also examine the inverse path, that is, routinespractices.

In view of the importance that practitioners represent for the activation of routines and, therefore, for DC development, it is additionally recommended that research be carried out that emphasizes the role played by practitioners in the strategic elaboration process. They could also consider questions related to their level of participation (operational, organizational, and strategic).

Finally, considering that only one organization from a specific sector was analyzed, research efforts should be encouraged about the learningpractices-routines trinomial in a set of organizations from the same sector, so as to evaluate the existence of patterns in DC development. 


\section{APRENDIZAGEM, STRATEGIZING E ROTINAS ORGANIZACIONAIS NO PROCESSO DE DESENVOLVIMENTO DE PRODUTO SOB A PERSPECTIVA DAS CAPACIDADES DINÂMICAS}

\section{RESUMO}

Objetivo: Compreender como a aprendizagem, os elementos constituintes do strategizing e as rotinas organizacionais atuam no processo de desenvolvimento de produto, sob a perspectiva das capacidades dinâmicas (CD), em uma empresa do setor alimentício.

Originalidade/valor: Na medida em que se aborda o trinômio aprendizagem-práticas-rotinas, os resultados desta pesquisa apresentam novos e esclarecedores insights para o entendimento de como as CD são desenvolvidas. Ademais, ao considerar o papel dos praticantes na constituição das rotinas e identificar como elas se relacionam com as práticas e práxis, as evidências avançam no conhecimento acerca da temática.

Design/metodologia/abordagem: Trata-se de abordagem qualitativa, mediante a seleção de uma empresa que tem atuado, ao longo do tempo, no desenvolvimento de novos produtos. Os dados foram coletados por meio de observação não participante, análise documental e entrevista narrativa. A análise dos dados ocorreu por meio da análise de narrativas. Resultados: Por meio da apropriação das práticas e da institucionalização das práxis, as rotinas estratégicas são ativadas pelos praticantes, os quais acumulam e geram aprendizado capaz de desenvolver CD. Assim, o trinômio aprendizagem-práticas-rotinas permite revelar como as $\mathrm{CD}$ são desenvolvidas. Ademais, foi evidenciado o importante papel que praticantes desempenham nesse processo no sentido de que sem eles rotinas não são ativadas e, consequentemente, não ocorre desenvolvimento de CD.

\section{PALAVRAS-CHAVE}

Capacidades dinâmicas. Aprendizagem. Strategizing. Rotinas. Desenvolvimento de produto. 


\section{REFERÊNCIAS}

Amit, R., \& Schoemaker, P. J. H. (1993). Strategic assets and organizational rent. Strategic Management Journal, 14(1), 33-46. doi:10.1002/smj.4250 140105

Arndt, F., Fourné, S. P. L., \& Macinerney-May, K. (2018). The merits of playing it by the book: Routine versus deliberate learning and the development of dynamic capabilities. Industrial and Corporate Change, 27(4), 723743. doi:10.1093/icc/dty005

Baum, J., \& Dobbin, F. (Eds.) (2000). Economics meets sociology in strategic management (Vol. 17, pp. xiii-xiv). Bingley: Emerald. doi:10.1016/S0742$3322(00)$ 17004-4

Belmondo, C., \& Roussel, C. S. (2014). Strategising routines as the missing link between strategy practices and praxis. Conférence Internationale de Management Stratégique, Rennes, France, 23.

Biesenthal, C., Gudergan, S., \& Ambrosini, V. (2019). The role of ostensive and performative routine aspects in dynamic capability deployment at different organizational levels. Long Range Planning, 52, 350-365. doi:10.1016/j.lrp.2018.03.006

Bingham, C. B., Heimeriks, K. H., Schijven, M., \& Gates, S. (2015). Concurrent learning: How firms develop multiple dynamic capabilities in parallel. Strategic Management Journal, 36 (12), 1802-1825. doi:10.1002/smj.2347

Cardoso, A. L. J., \& Kato, H. T. (2015). Análise das publicações sobre capacidades dinâmicas entre 1992 e 2012: Discussões sobre a evolução conceitual e as contribuições dos autores de maior notoriedade na área. Revista de Administração Mackenzie, 16(3), 201-237. doi:10.1590/1678-69712015

Creswell, J. W. (2013). Qualitative inquiry \& research design: Choosing among five approaches (3rd ed.). Thousand Oaks, CA: Sage.

Eisenhardt, K. M., \& Martin, J. A. (2000). Dynamic capabilities: What are they? Strategic Management Journal, 21, 1105-1121. doi:10.1002/1097-0266 (200010/11)21:10/11<1105::AID-SMJ133>3.0.CO;2-E

Feldman, M. S. (2015). Theory of routines dynamics and connections to strategy as practice. In D. Golsorkhi, L. Rouleau, D. Seidl, \& E. Vaara, Cambridge handbook of strategy as practice (2nd ed., pp. 547-563). Cambridge: Cambridge University Press.

Feldman, M. S., \& Pentland, B. T. (2003). Reconceptualizing organizational routines as a source of flexibility and change. Administrative Science Quarterly, 48, 94-118. doi:10.2307/3556620 
Feldman, M. S., \& Worline, M. C. (2012). Resources, resourcing, and ampliative cycles in organizations. In K. S. Cameron \& G. M. Spreitzer (Eds.), The Oxford handbook of positive organizational scholarship (pp. 629-641). Oxford: Oxford University Press.

Garcia, A. E. G. (2017). A inteligência competitiva e o desenvolvimento de capacidades dinâmicas nas organizações. Revista Ibero-Americana de Estratégia, 16(1), 69-90. doi:10.5585

Giniuniene, J., \& Jurksiene, L. (2015). Dynamic capabilities, innovation and organizational learning: Interrelations and impact on firm performance. Procedia-Social and Behavioral Sciences, 213, 985-991. doi:10.1016/j.sbspro. 2015.11.515

Helfat, C. E., Finkelstein, S., Mitchell, W., Peteraf, M., Singh, H., Teece, D. J., \& Winter, S. G. (2007). Dynamic capabilities: Understanding strategic change in organizations. Malden, MA: Blackwell.

Jarzabkowski, P. (2005). Strategy as practice: An activity based approach (2nd ed.). California: Sage.

Jarzabkowski, P., Balogun, J., \& Seidl, D. (2007). Strategizing: The challenges of a practice perspective. Human Relations, 60(1), 5-27. doi:10.1177/0018 726707075703

Johnson, G., Melin, L., \& Whittington, R. (2003). Guest editors' introduction: micro strategy and strategizing: Towards an activity-based view. Journal of Management Studies, 40(1), 3-22.

Jovchelovitch, S., \& Bauer, M. W. (2002). Entrevista narrativa. In M. W. Bauer \& G. Gaskell (Orgs.), Pesquisa qualitativa com texto, imagem e som: Um manual prático. Petrópolis: Vozes.

Maranzato, F. P., \& Salerno, M. S. (2018). Integração entre pesquisa e desenvolvimento: Uma perspectiva de capacidades dinâmicas. Revista de Administração de Empresas, 58(5), 460-474. doi:10.1590/s0034-7590201 80503

Meira, M. M., Machado, A. G. C., \& Gomes, G. R. S. (2019). Dynamic capabilities for accreditation: Evidence in the healthcare sector. Brazilian Administration Review, 16 (1), 1-25. doi:10.1590/1807-7692bar2019180115

Meirelles, D. S., \& Camargo, A. A. B. (2014). Capacidades dinâmicas: O que são e como identificá-las? Revista de Administração Contemporânea, 18(Ed. Esp.), 41-64. doi:10.1590/1982-7849rac20141289

Milagres, R. (2011). Rotinas: Uma revisão teórica. Revista Brasileira de Inovação, 10(1), 161-196. doi:10.20396/rbi.v10i1.8649013 
Pavlou, P. A., \& El Sawy, O. A. (2011). Understanding the elusive black box of dynamic capabilities. Decision Sciences, 42(1), 239-273. doi:10.1111/j. 1540-5915.2010.00287.x

Pentland, B. T. (1999). Building process theory from narrative: From description to explanation. Academy of Management Review, 24(4), 711-724. doi:10. $2307 / 259350$

Pentland, B. T., \& Feldman, M. S. (2005). Organizational routines as a unit of analysis. Industrial and Corporate Change, 14(5), 793-815. doi:10.1093/ icc/dth070

Peteraf, M. A. (2005). Research complementarities: A resource-based view of the resource allocation process model (and vice versa). In J. L. Bower \& C. G. Gilbert (Eds.), From resource allocation to strategy (pp. 409-426). Oxford: Oxford University Press.

Regnér, P. (2008). Strategy-as-practice and dynamic capabilities: Steps towards a dynamic view of strategy. Human Relations, 61 (4), 565-588. doi:10.1177/0018726708091020

Rouleau, L. (2011). Studying strategizing through narratives of practice. In D. Golsorkhi, L. Rouleau, D. Seidl, \& E. Vaara, Cambridge Handbook of Strategy as Practice (pp. 258-270). Cambridge: Cambridge University Press.

Silva, S. S. S., \& Lucena, E. A. (2015). How have managers learned about the application of monitoring routine? Gestão \& Produção, 22(2), 356-369. doi:10.1590/0104-530X513-13

Tallott, M., \& Hilliard, R (2016). Developing dynamic capabilities for learning and internationalization: A case study of diversification in an SME. Baltic Journal of Management, 11 (3), 328-347. doi:10.1108/BJM-02-2015-0060

Teece, D. J., Pisano, G., \& Shuen, A. (1997). Dynamic capabilities and strategic management. Strategic Management Journal, 18(7), 509-533. doi:10. 1002/(SICI) 1097-0266(199708) 18:7 <509::AID-SMJ882>3.0.CO;2-Z

Vargas-Hernández, J. G., \& Muratalla-Bautista, G. (2017). Dynamic capabilities analysis in strategic management of learning and knowledge absorption. Revista de Administração, Contabilidade e Economia, 16(1), 227-260. doi:10.18 593/race.v16i1.10997

Whittington, R. (2006). Completing the practice turn in strategy research. Organization Studies, 27(5), 613-634. doi:10.1177/0170840606064101

Whittington, R., Johnson, G., \& Melin, L. (2004). The emerging field of strategy practice: Some links, a trap, a choice and a confusion. Proceedings of the Egos Colloquium, Ljubljana, Slovenia. 
Wohlgemuth, V., \& Wenzel, M. (2015). Dynamic capabilities and routinization. Journal of Business Research, 69(5), 1-5. doi:10.1016/j.jbusres.2015. 10.085

Zollo, M., \& Winter, S. G. (2002). Deliberate learning and the evolution of dynamic capabilities. Organization Science, 13, 339-351. doi:10.1287/orsc. 13.3.339.2780

\section{AUTHOR NOTES}

Germana T. Melo, Ph.D from the Postgraduate Program in Management (PPGA), Federal University of Paraíba (UFPB); André G. C. Machado, Ph.D from the Postgraduate Program in Management (Propad), Federal University of Pernambuco (UFPE).

Germana T. Melo is now assistant professor II at the Department of Social and Applied Sciences (DCSA) of the Federal University of Paraíba (UFPB); André G. C. Machado is now associate professor at the Department of Management of the Federal University of Paraíba (UFPB).

Correspondence concerning this article should be addressed to Germana T. Melo, campus universitário III, Rua João Pessoa, s/n, Bananeiras, Paraíba, Brazil, CEP 58220-000.

E-mail: germana_@hotmail.com

EDITORIAL BOARD

Editor-in-chief

Gilberto Perez

Associated Editor

Márcia da Mota Darós

Technical support

Vitória Batista Santos Silva
EDITORIAL PRODUCTION

Publishing coordination

Jéssica Dametta

Layout designer

Emap

Editorial intern

Paula Di Sessa Vavlis

Graphic designer

Libro
Language editor

Daniel de Almeida Leão 